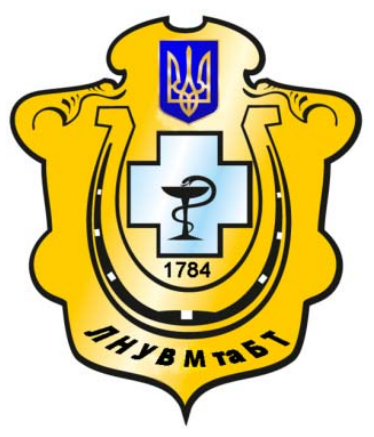

Науковий вісник Львівського національного університету ветеринарної медицини та біотехнологій імені С.3. Гжицького

Scientific Messenger of Lviv National University of Veterinary Medicine and Biotechnologies named after S.Z. Gzhytskyj

doi:10.15421/nvlvet6630

ISSN 2413-5550 print

ISSN 2518-1327 online

$\underline{\text { http://nvlvet.com.ua/ }}$

УДК 636.085.3:619:616.992.28

\title{
Заходи боротьби з асоційованим проявом пастерельозу, стафілококозу та вірусного стоматиту кролів в умовах приватного господарства Полтавського району
}

\author{
О.О. Передера, І.В. Лавріненко, І.А. Жерносік \\ ua151@ukr.net \\ Полтавська державна аграрна академія \\ вул. Сковороди, 1/3, м. Полтава, 36003, Украӥна
}

\begin{abstract}
У статті наведено епізоотологічні дані, клінічні ознаки, патологоанатомічні зміни та результати лабораторних досліджень за асоиійованого прояву пастерельозу, стафілококозу та вірусного стоматиту кролів. Робота виконувалася у 2016 рочі у приватному господарстві Полтавської області. Діагностику здійснювали комплексно: з урахуванням симптомів захворювання та результатів мікроскопічних та бактеріологічних досліджень.

Захворювання зареєстрували у трьохмісячних кроленят. Тварини худли, відчували сильну спрагу, ставали пригніченими, малорухливими. Апетит, як правило, на початку захворювання не змінювався, але з розвитком клінічних ознак погіршувався. Розвивався риніт, спочатку серозний, потім слизово-гнійний. Крім розладів функцій органів дихання спостерігалась дисфункція шлунково-кишкового тракту - проноси чергувалися із запорами, черевце ставало м'яким, не пружнім. Основною клінічною ознакою в ией період було прогресуюче зневоднення: сухість і анемічність видимих слизових оболонок, западання очей вглиб орбіти. Задня частина тулуба була забруднена каловими масами рідкої консистенції. Хутро тьмяніло, шерсть ставала скуйовдженою, легко виймалася з волосяних фолікулів. В куточках очей накопичувалася значна кількість слизовогнійного ексудату, що в окремих випадках призводило до склеювання повік. Кроленята гинули на фоні прогресуючої слабкості. При розтині трупів загиблих виявляли ознаки серозно-геморагічної або серозно-фібринозної пневмонії, серозногеморагічного плевриту та перитоніту. Реєстрували спленіт, в кишківнику - потовщення стінки, ознаки гострого катарального ентериту, численні крововиливи на слизовій оболонці та ознаки венозного застою.

При розробиі заходів боротьби враховували наявність асочіачії. У даному господарстві одночасно з асоиійованим пастерельозом було діагностовано еймеріоз, тому крім антибактеріальних речовин виникала необхідність у застосуванні еймеріостатиків. Виділені збудники пастерельозу і стафілококозу виявляли чутливість до енрофлоксацину та тилозину. Тваринам однієї групи був застосований комплексний препарат бровасептол, у іншій застосували препарат тилозин $50 \%$ та салікокс. Високий лікувальний ефект забезпечило застосування біопрепаратів серед тварин обох груп. Застосування тилозину було ефективним як окремо, у поєднанні з солікоксом, так і при застосуванні комплексного препарату бровасептол. Через тиждень після одужання тварин проводили щееллення усіх кролів вакциною Пазорін-Oль, (Pasorin-Ol).

Ключові слова: кролі, пастерельоз, стафілококоз, вірусний стоматит, еймеріоз, антибіотики, чутливість, лікування, заходи боротьби, патолого-анатомічні зміни.
\end{abstract}

\section{Меры борьбы с ассоциированным проявлением пастереллеза, стафилококкоза и вирусного стоматита кроликов в условиях частного хозяйства Полтавского района}

\author{
Е.А. Передера, И.В. Лавриненко, И.А. Жерносик \\ ua151@ukr.net
}

Полтавская государственная аграрная академия, ул. Сковороды, 1/3, г. Полтава, 36003, Украина

\section{Citation:}

Peredera, O.O., Lavrinenko, I.V., Zhernosik, I.A. (2016). Measures to combat manifestations associated pasteurellosis, stafilokokozes and rabbits viral stomatitis under private sector in Poltava region. Scientific Messenger LNUVMBT named after S.Z. Gzhytskyj, 18, 2(66), 144-151. 
В статье приведены эпизоотологические данные, клинические признаки, патологоанатомические изменения и результаты лабораторных исследований при ассочиированном проявлении пастереллеза, стафилококкоза и вирусного стоматита кроликов. Работа выполнялась в 2016 году в частном хозяйстве Полтавской области. Диагностику осуиествляли комплексно: с учетом клинических признаков заболевания и результатов микроскопических и бактериологических исследований.

Заболевания зарегистрировали у трехмесячных крольчат. Животные худели, испьтывали сильную жажду, становились угнетенными, малоподвижными. Аппетит, как правило, в начале заболевания не менялся, но с развитием клинических признаков ухудшался. Развивался ринит, сначала серозный, затем слизисто-гнойный. Кроме расстройств функиий органов дыхания наблюдалась дисфункиия желудочно-кишечного тракта - понось чередовались с запорами, брюшко становилось мягким. Основным клиническим признаком в этот период было прогрессирующее обезвоживание: сухость и анемичность видимых слизистых оболочек, западение глаз вглубь орбиты. Задняя часть туловища была загрязнена калом жидкой консистенции. Мех тускнел, шерсть становилась взъерошенной, легко вынималась из волосяных фолликулов. В уголках глаз накапливалась значительное количество слизисто-гнойного экссудата, что в отдельных случаях приводило к склеиванию век. Крольчата погибали на фоне прогрессирующей слабости.

При вскрытии трупов погибших обнаруживали признаки серозно-геморрагической или серозно-фибринозной пневмонии, серозно-геморрагического плеврита и перитонита. Регистрировали спленит, в кишечнике - утолщение стенки, признаки острого катарального энтерита, многочисленные кровоизлияния на слизистой оболочке и признаки венозного застоя.

При разработке мер борьбы учитывали наличие ассоциации. В данном хозяйстве одновременно с ассоциированным пастерелезом был диагностирован еймериоз, поэтому кроме антибактериальных веществ возникала необходимость в применении еймериостатиков. Выделенные возбудители пастереллеза и стафилококкоза проявляли чувствительность к энрофлоксацину и тилозину. Животным одной группы был применен комплексный препарат Бровасептол, в другой применили препарат тилозин 50\% и саликокс. Высокий лечебный эффект обеспечило применение биопрепаратов среди животных обеих групп. Применение тилозина было эффективным как отдельно, в сочетании с соликоксом, так и при применении комплексного препарата Бровасептол. Через неделю после выздоровления животных проводили прививки всех кроликов вакииной Пазорин-Оль, (Pasorin-Ol).

Ключевые слова: кролики, пастерельоз, стафилококоз, вирусный стоматит, эймериоз, антибиотики, чуствительность, лечение, меры борьбы, патолого-анатомические изменения.

\title{
Measures to combat manifestations associated pasteurellosis, stafilokokozes and rabbits viral stomatitis under private sector in Poltava region
}

\author{
O.O. Peredera, I.V. Lavrinenko, I.A. Zhernosik \\ ua151@ukr.net
}

Poltava State Agrarian Academy

Skovorody Str., 1/3, Poltava, 36003,Ukraine

In the article epizootological data, clinical signs, pathological changes and laboratory research associate for the manifestation of pasteurellosis, stafilokokos and viral stomatitis of rabbits. The work was performed in 2016 in the private sector Poltava region. Diagnostics performed comprehensively, taking into account symptoms and results of microscopic and bacteriological research.

The disease is filed within three rabbits. Animals lost weight, felt very thirsty, became depressed, inactive. Appetite is usually in early disease did not change, but with the development of clinical signs deteriorated. Developed rhinitis, first serous then mucopurulent. In disorders of respiratory function observed dysfunction of the gastrointestinal tract - diarrhea alternating with constipation, the abdomen becomes soft, not firm. The main clinical feature of this period was a progressive dehydration: dry and anemichnist visible mucous membranes, eyes retraction deep into orbit. The back of the body was contaminated liquid stool consistency. Fur becomes darker, hair becomes disheveled, easily removed from hair follicles. In the corners of the eyes accumulated significant amount of muco-purulent fluid, which in some cases led to a adhesive forever. Rabbits died on the background of progressive weakness.

Autopsy of the dead showed signs of sero-hemorrhagic or sero-fibrinous pneumonia, sero-hemorrhagic pleurisy and peritonitis. Recorded splenit in bowel - wall thickening, signs of acute catarrhal enteritis, multiple hemorrhages in the mucosa and signs of venous congestion.

In developing control measures take into account the existence of the association. In this economy together with the associated pasteurellosis was diagnosed eymeriosis because besides antibacterial substances it was necessary to use eymeriostatyks. Dedicated pathogens of stafilokokosis and pasteurellosis showed sensitivity to enrofloxacin and tylosin. Animals of one group was used brovaseptol complex preparation, the drug used in another 50\% of tylosin and salikoks. The high therapeutic effect provided the use of biologics in animals of both groups. The use of tylosin were effective individually in combination with solikoks and the application of complex drug brovaseptol. A week after recovery animals were immunized rabbits all vaccine Pazorin-Ol, (Pasorin-Ol).

Key words: rabbits, pasteurellosis, stafilokokoz, viral stomatitis, eymerioz, antibiotics, sensitivity, treatment and control measures, pathological-anatomical changes.

\section{Вступ}

Пастерельози - інфекційні захворювання усіх видів домашніх і диких тварин, що викликаються мікроорганізмами 3 роду Pasteurella. Характеризуються геморагічним діатезом, явищами септицемії, ураженням органів дихання і травлення, а також набряками підшкірної клітковини та міжм'язової сполучної тканини (Trishkina and Parfenov, 1987; Evtushenko, 1992; Sosnyc'kyj, 2003). Стафілококові захворювання найча- 
стіше розвиваються серед кролів у літні місяці та в період окролів. Основним джерелом збудника $\epsilon$ хворі тварини та носії збудника. Збудник може виділятися 3 усіма секретами і екскретами в залежності від форми. Проникнення в організм відбувається аліментарно, аерогенно, через слизові оболонки та пошкоджену шкіру. Фактори передачі - корми, вода, предмети догляду та інвентар, контамінований збудником. Збудник може переноситися механічно кровосисними комахами і мухами.

Встановлено, що в Україні, у господарствах різних форм власності Луганської, Полтавської, Запорізької, Сумської областей, в останні роки відмічається розповсюдження пастерельозу та збільшення вогнищ інфекцій, що загострює епізоотичну ситуацію та створює передумови для виникнення і прояву інших інфекційних захворювань бактеріальної і вірусної етіології (Zabolotnaja and Sosnickij, 1999; Zabolotna, 2005).

Метою роботи - вивчення чинників, що впливають на перебіг ензоотії пастерельозу в асоціації зі стафілококозом та вірусним стоматитом кролів і врахування цих факторів при проведенні заходів ліквідації.

\section{Матеріал і методи досліджень}

Робота виконувалася у 2016 році у приватному господарстві Полтавської області. Спочатку вивчали ветеринарно-санітарний та епізоотичний стан господарства; умови утримання та годівлі тварин, сезонність виникнення епізоотії, загальні тенденції іiі розвитку. Особливу увагу приділяли вивченню клінічних ознак і патологоанатомічних змін при спонтанному пастерельозі; проводили заходи щодо ліквідації спалаху. Діагностику здійснювали комплексно: з урахуванням симптомів захворювання та результатів мікро- скопічних та бактеріологічних досліджень. Клінічні дослідження виконувалися загальноприйнятими методами, включаючи детальний анамнез. Патологоанатомічний розтин трупів проводили методом евісцерації. Звертали увагу на положення органів, їх форму та розміри, враховували колір, консистенцію та малюнок. Для вивчення морфології мікроорганізмів мазки, 3 виділених культур фарбували спиртово-водним розчином метиленового синього. Вивчали чутливість виділеної мікрофлори до окремих антибактеріальних препаратів: амоксіцилін (20 мкг), доксіциклін (30 мкг), гентаміцин (120 мкг), тілозин (15 мкг), цефазолін (30 мкг), енрофлоксацин (5 мкг), тетрациклін (30мкг) та бензилпеніцилін (10 ОД) методом дифузії в агар iз застосуванням дисків виробництва науководослідного центру фармакотерапії (Санкт-Петербург, Росія).

\section{Результати та їх обговорення}

Захворювання було зареєстроване на початку березня 2016 року. Його поширення серед тварин характеризувалося високою динамічністю.

Захворювання зареєстрували у трьохмісячних кроленят. Тварини худли, відчували сильну спрагу. Інтенсивна слинотеча проявлялася у всіх хворих, що було яскравою клінічною ознакою вірусного стоматиту «мокра мордочка» (рис.1).

Спочатку помічалося почервоніння слизової оболонки рота. Однак сухості їі не спостерігалося - слизова залишалася вологою. Незабаром на спинці і бічних краях кінчика язика, а часто і на слизовій оболонці верхньої губи, в області беззубого краю, з'являлися тонкі білуваті плівки у вигляді дрібних цяток і смужок, які незабаром зливалися в суцільний наліт.

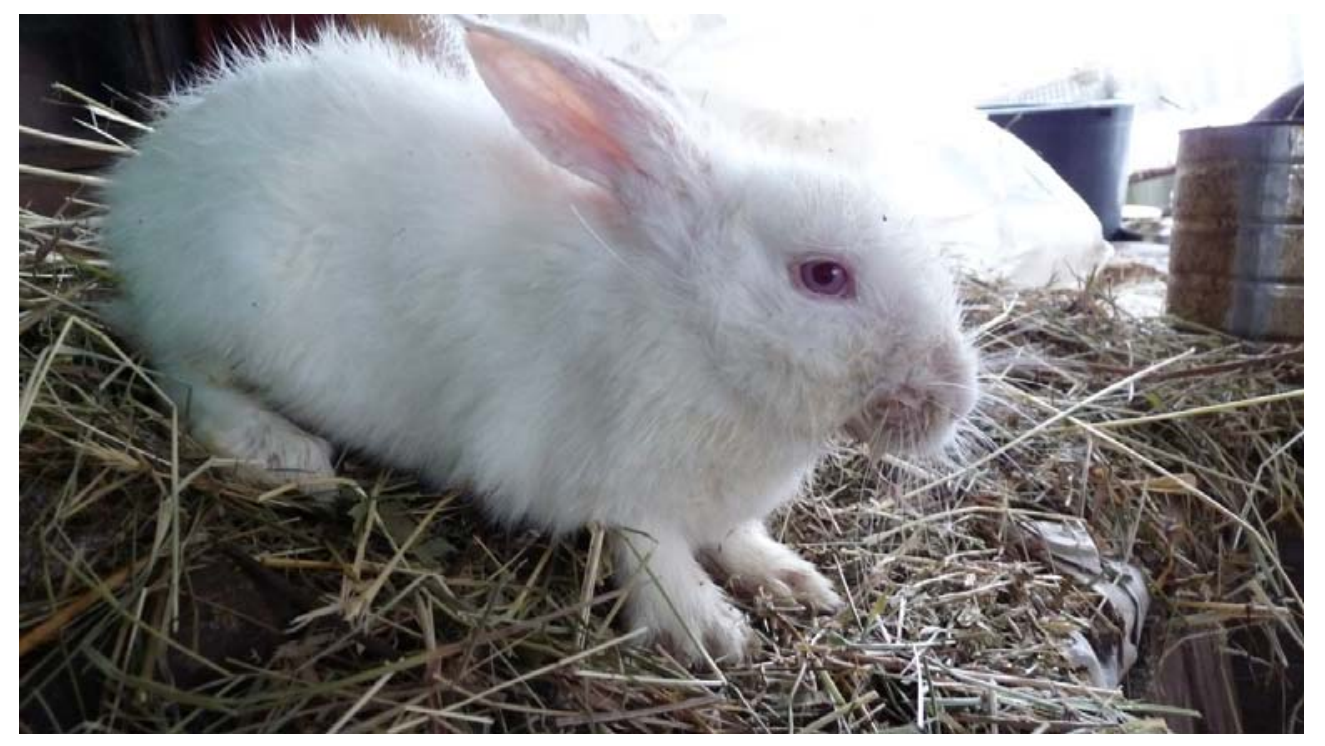

Рис. 1. Клінічні ознаки за вірусного стоматиту кроля

Уражена ділянка відмежовувалася від нормальної слизової червоною облямівкою шириною 1 мм. Слизова оболонка спинки тіла язика в області подушки набрякала, ставала білого кольору. Виникала слинотеча. Спочатку слина виділялася тільки в області ку- тів рота. В результаті змочування слиною волосся вони склеювалися, утворюючи «вусики» у вигляді темної смужки.

На наступний день слинотеча посилювалася. Біла піниста слина виділялася вже по всьому губному 
краю ротової щілини. Кроленя терло лапками мордочку, змочуючи при цьому волосяний покрив лапок, підгрудка і всієї мордочки. Шерсть на цих частинах тіла склеювалася слиною. 3 появою слинотечі змінювався і загальний стан кроленят. Вони ставали пригніченими, малорухливими. Хворі, зазвичай, забивалися в кут клітки і робили жувальні рухи щелепами, видаючи характерне чавкання. Апетит у хворих не втрачався, вони підходили до годівниць, але через болючість в ротовій порожнині їдли мало. В результаті хворі кроленята швидко худнули. Через 1-2 доби у захворівших тварин починалися розлади шлунковокишкового тракту. Шерсть ставала скуйовдженою та брудною. У тварин реєстрували анорексію, кон'юнктивіти, риніти. Апетит, як правило, на початку захворювання не змінювався, але з розвитком клінічних ознак погіршувався. Тварини втрачали вагу, кінці вух звисали, слизова оболонка носа була 3 синюшним відтінком. У цей період розвивався риніт, спочатку серозний, потім слизово-гнійний. Крім розладів функцій органів дихання спостерігалась дисфункція шлунково-кишкового тракту - проноси чергувалися із запорами, черевце ставало м'яким, не пружнім. Поїдання грубих кормів або навіть невеликої кількості зелених кормів провокувало атонію і здуття шлунка та кишечнику. Основною клінічною ознакою в цей період було прогресуюче зневоднення: сухість і анемічність видимих слизових оболонок, западання очей вглиб орбіти. Задня частина тулуба була забруднена каловими масами рідкої консистенції. Хутро тьмяніло, шерсть ставала скуйовдженою, легко виймалася 3 волосяних фолікулів. В куточках очей накопичувалася значна кількість слизово-гнійного ексудату, що в окремих випадках призводило до склеювання повік. Кроленята гинули на фоні прогресуючої слабкості.

Температура тіла протягом хвороби залишалася нормальною. На 4-5-й день білий наліт у ротовій порожнині набував буруватого або жовтуватого забарвлення, після чого він починав поступово відторгатися, залишаючи смужкові ерозії різного розміру. Поверхня спинки язика ставала брудного сіруваточервоного кольору. В ділянці подушки епітелій злущувався, утворювалися круглі або овальні виразки.

У перехворілих кроленят шерсть в області мордочки і особливо підщелепового простору довгий час залишалася засохлою і склеєною, а часто і зовсім випадала. На оголеній шкірі нижньої щелепи і підщелепового простору іноді утворювалися дрібні гнійники. У такому стані тварини швидко гинули на фоні крайнього пригнічення.

Через декілька діб почалося захворювання серед чотирьохмісячних кроленят. У них спостерігали здуття черевця, діарею, зневоднення. Температура тіла підвищувалася до $41,5^{\circ} \mathrm{C}$.

Тупи загиблих кроленят були виснажені, шерсть у задній частині тулуба забруднена фекальними масами. Слизові оболонки анемічні. Патологоанатомічні зміни, зареєстровані при розтині трупів тварин, були подібними. У всіх тварин виявляли значну кількість кров'янистої рідини в грудній і черевній порожнині. При проведенні патологоанатомічних розтинів за надгострого та гострого перебігу пастерельозу, відмічали збільшення розмірів легень. В органах дихальної системи виявляли гіперемію та смугасті крововиливи на слизовій оболонці трахеї (рис. 2).

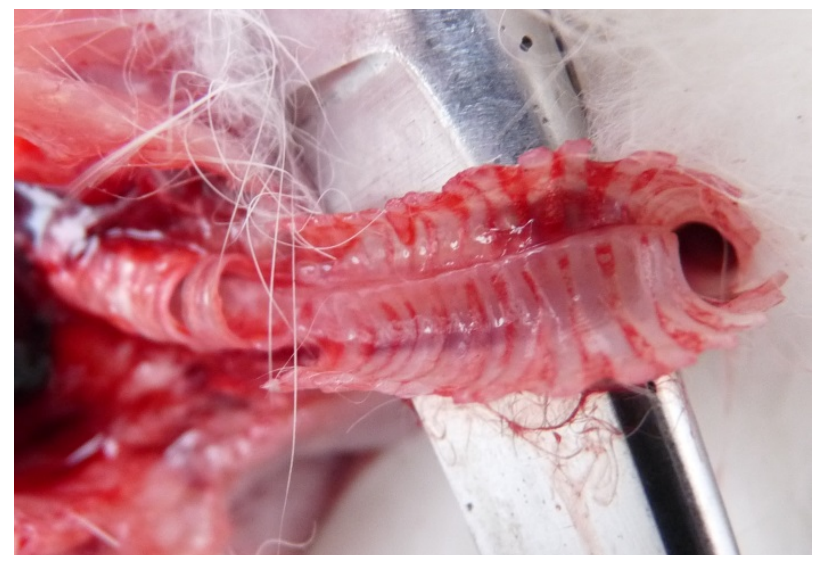

Рис. 2. Крововиливи на слизовій оболонці трахеї та пінистий кров'янистий ексудат у просвіті

Також виявляли ознаки серозно-геморагічної або серозно-фібринозної пневмонії (рис. 3), на розрізі світло-червоний ексудат.

У всіх загиблих тварин виявляли гіпертрофію міокарду (рис. 3). Серце було збільшене у розмірах, м'яке. На епікарді - численні крапкові крововиливи.

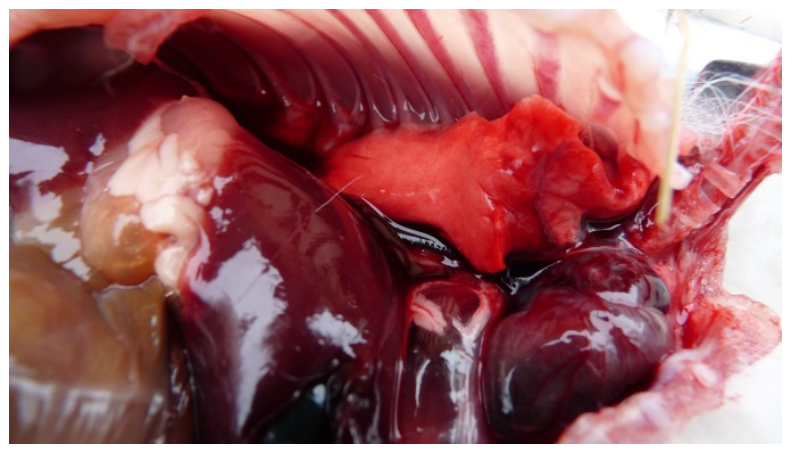

\section{Рис. 3. Значна кількість кров'янистої рідини у порожнинах, зміни легень та серця}

Виявляли ознаки серозно-геморагічного плевриту та перитоніту. Реєстрували спленіт: селезінка була збільшена, темно-вишневого кольору, часто з некрозами крайових частин. Внаслідок серцевої недостатності розвивалася венозна гіперемія органів черевної порожнини.

При розтині трьохмісячних кроленят основні зміни реєстрували в кишківнику: потовщення стінки, ознаки гострого катарального ентериту, численні крововиливи на слизовій оболонці та ознаки венозного застою.

Спостерігали зміни, характерні для гострого нефриту: нирки збільшені, паренхіма вогнищевогіперемійована. Межа коркової та мозкової зони не чітка, у кірковій зоні - численні крововиливи.

Капсула печінки була напруженою. Жовчний міхур - збільшений, наповнений жовчю темно-зеленого 
кольору (рис. 4). Спостерігалося незначне збільшення об'єму органу та його ущільнення. Забарвлення органу було рівномірним, характерним для гострого септичного гепатиту.

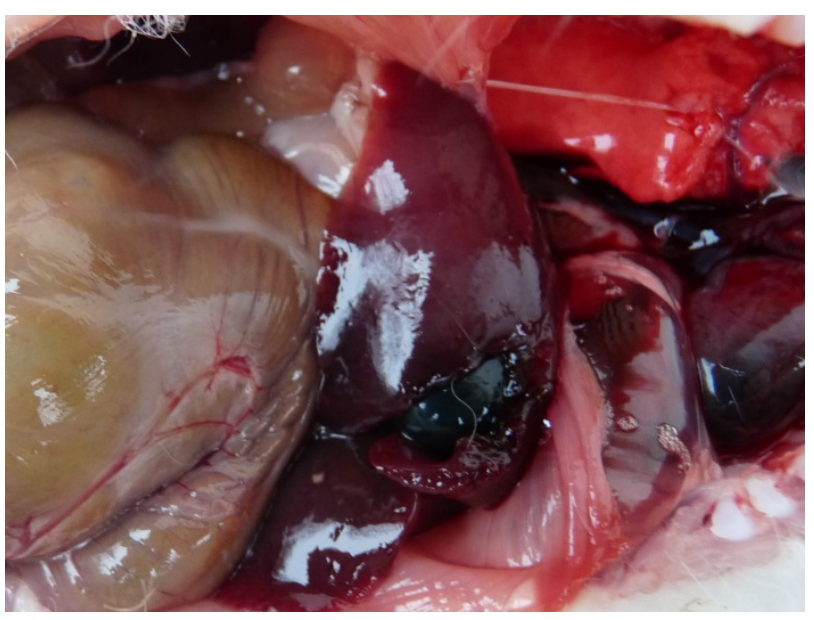

Рис. 4 Ознаки гострого гепатиту

У шлунку виявляли незначну кількість газів та катаральне запалення слизової оболонки. Інших патологоанатомічних змін не реєстрували.

У тонкому кишківнику - ознаки геморагічного запалення. У товстому відділі кишківника - здуття та невелика кількість щільних калових мас (рис.5).

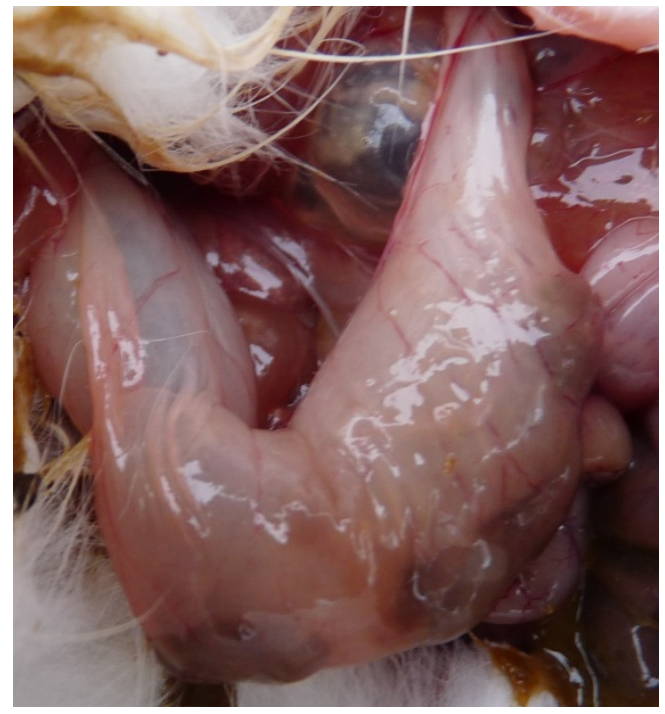

Рис. 5. Здуття шлунку за асоційованого пастерельозу

Діагноз на пастерельоз встановлювали комплексно, враховуючи епізоотологічні дані, клінічні ознаки, патолого-анатомічні зміни, та результати лабораторних досліджень. Для дослідження стерильним інструментом відбирали кров із серця, шматочки печінки, легень, лімфатичні вузли, кровянисту рідину із грудної та черевної порожнин та проводили посіви на МПА.

Після посіву чашки Петрі ставили у термостат при температурі $37,5^{\circ} \mathrm{C}$ і вели спостереження. Оскільки патолого-анатомічні ознаки були характерні для пастерельозу кролів, ми очікували ріст саме цього збудника.

Через 24 години на поживному середовищі виростали округлі, гладенькі, «воскові» колонії пастерел (рис.6, 7). Але серед цієї культури чітко виділялися інші колонії. Останні були більшими за розмірами та мали злегка жовтуватий відтінок.

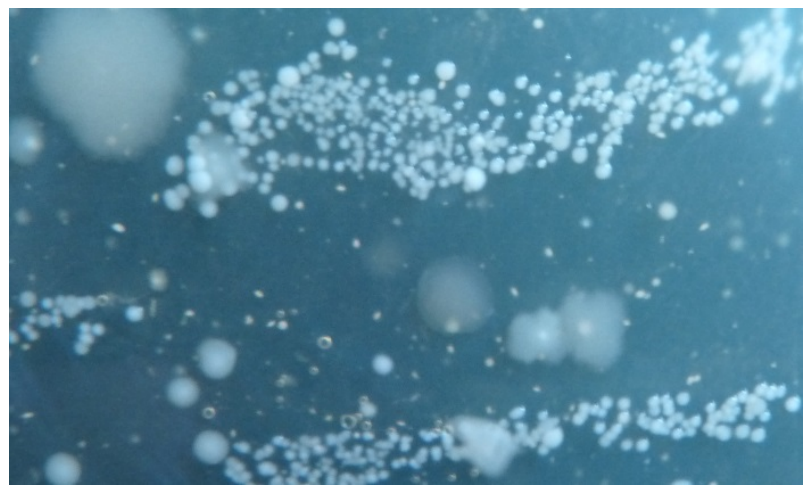

Рис.6. Ріст пастерел та стафілококів з ураженої легеневої тканини за гострого пастерельозу

Із дрібних колоній були зроблені мазки, які фарбували генціан-віолетом. У мазках із колоній були виявлені збудники пастерельозу - характерні біполярні палички.

У подальшому в результаті пересіву жовтуватих колоній, одержаних при посівах із патологічного матеріалу була одержана чиста культура збудника стафілококозу (рис. 7)

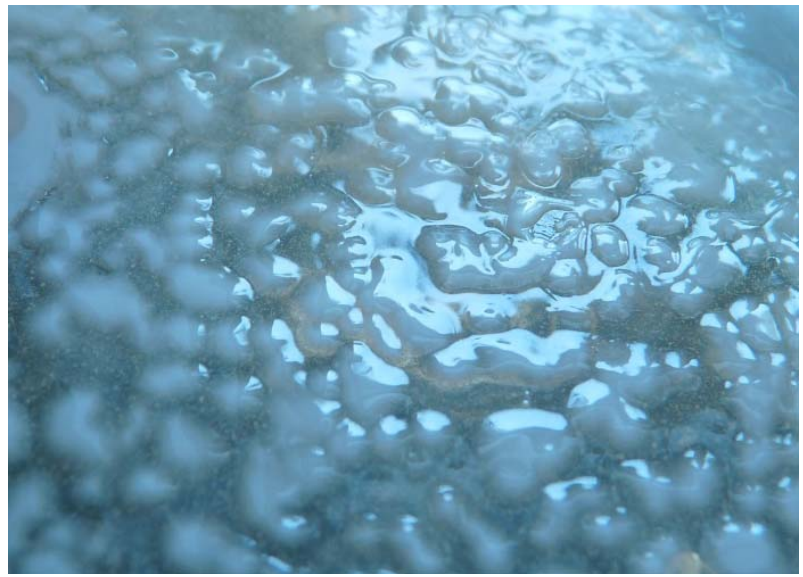

Рис. 7. Чиста культура збудника стафілококозу кролів

Із цих колоній були зроблені мазки, які фарбували генціан-віолетом. У мазках із колоній були виявлені стафілококи - у вигляді характерних виноградних грон (рис. 8).

Після отримання чистої культури проводили визначення чутливості пастерельозу та стафілококозу до різних антибактерійних речовин.

Використали диско-дифузійний метод, який включає кілька етапів: приготування поживного середовища, приготування суспензії мікроорганізмів та їх 
інокуляція, накладення дисків та інкубація, облік результатів.

Чашки Петрі діаметром 10 см поміщали на горизонтальну поверхню та заливали 30 мл розплавленого м'ясо-пептонного агару. Залишали при кімнатній температурі для застигання агару. Суспензію мікроорганізмів готували із 18 годинної агарової культури збудника. На поверхню агару вносили 1-2 мл суспензії, рівномірно розподіляючи іiі на поверхні агару. Через 15 хв після внесення суспензії мікроорганізмів на поверхню поживного середовища за допомогою стерильного пінцета наносили диски з антибіотиками (4-5 на одну чашку Петрі). Диски акуратно притискали пінцетом до поверхні агару. Після цього чашки поміщали в термостат догори дном та інкубували 18 годин при $37^{\circ} \mathrm{C}$. Після закінчення інкубації чашки Петрі розглядали та вимірювали у міліметрах зону затримки росту мікроорганізмів.

Результати оцінки визначення чутливості виділеної мікрофлори до окремих антибіотиків наведено в таблиці 1.
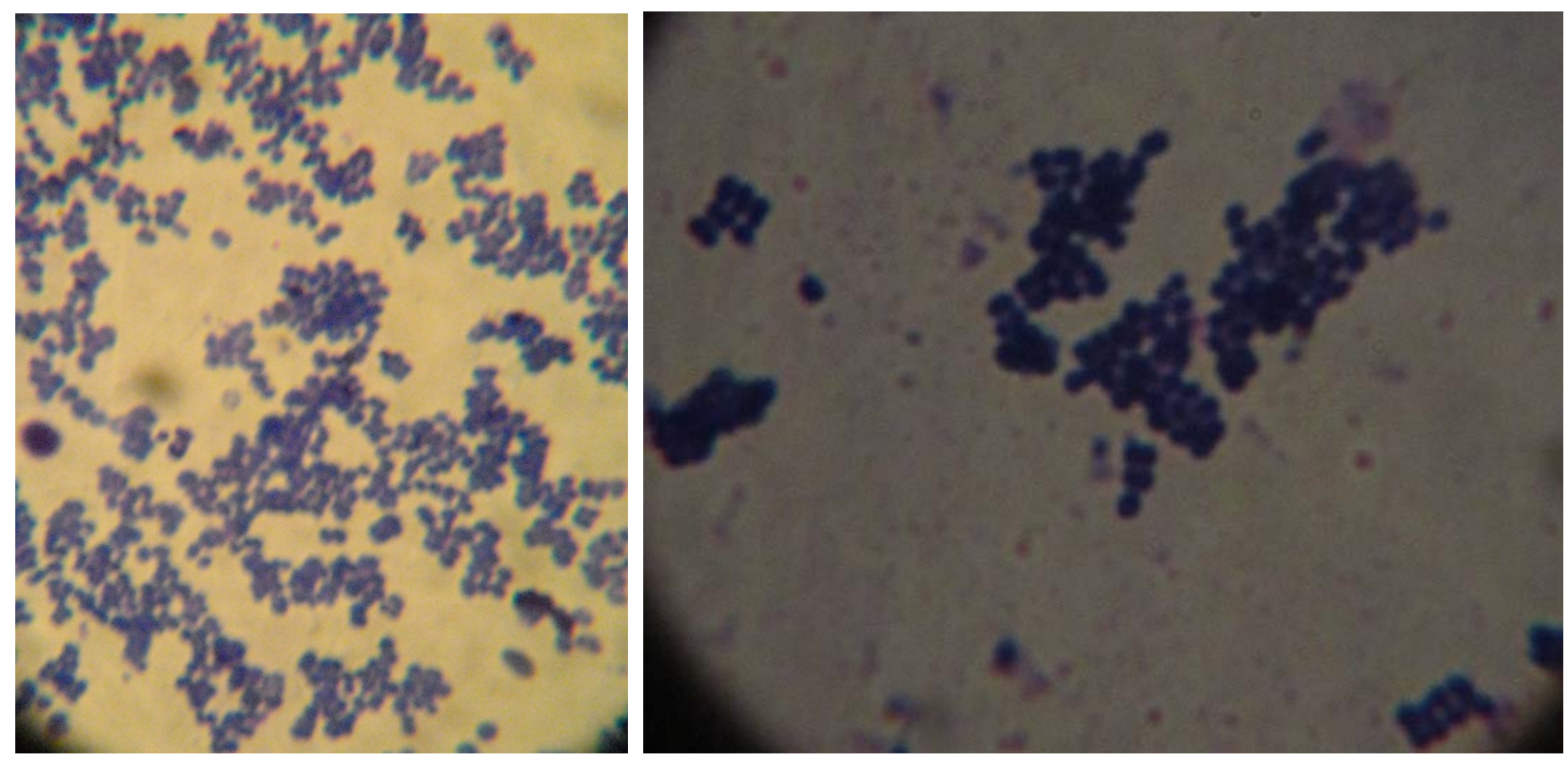

Рис. 8. Збудники стафілококозу у вигляді характерних виноградних грон (забарвлення генціан-віолетом, збх1500)

Таблиияя 1

Чутливість пастерел до окремих антибактерійних засобів

\begin{tabular}{|l|c|c|}
\hline \multicolumn{1}{|c|}{ Назва препарату } & Зона затримки росту мікрофлори, мм & Категорії чутливості \\
\hline Амоксіцилін & $2-4$ & Резистентний \\
\hline Доксіциклін & $2-4$ & Резистентний \\
\hline Поліміксин & - & Резистентний \\
\hline Тілозин & $14-21$ & Чутливий \\
\hline Енрофлоксацин & $21-23$ & Чутливий \\
\hline Тетрациклін & - & Резистентний \\
\hline Неоміцин & $4-6$ & Резистентний \\
\hline Цефазолін & $2-4$ & Резистентний \\
\hline Левоміцетин & $9-12$ & Помірно-стійкий \\
\hline Канаміцин & $10-14$ & Помірно-стійкий \\
\hline
\end{tabular}

Згідно до одержаних результатів, виділені культури пастерел виявили високу чутливість до тілозину та енрофлоксацину (рис. 9).

Окремо визначали чутливість виділеного збудника стафілококозу кролів. Для цього використовували аналогічні диски 3 антибактерійними речовинами (таблиця 2).
До більшості досліджуваних антибактерійних засобів виділений збудник стафілококозу був не чутливий. До амоксіциліну, доксіцикліну, поліміксину, тетрацикліну, цефазоліну та неоміцину виділена мікрофлора була резистентною, препарати не впливали на ріст даних мікроорганізмів. Зона затримки росту мікрофлори коливалася від 0 до 8 мм (рис.10). 


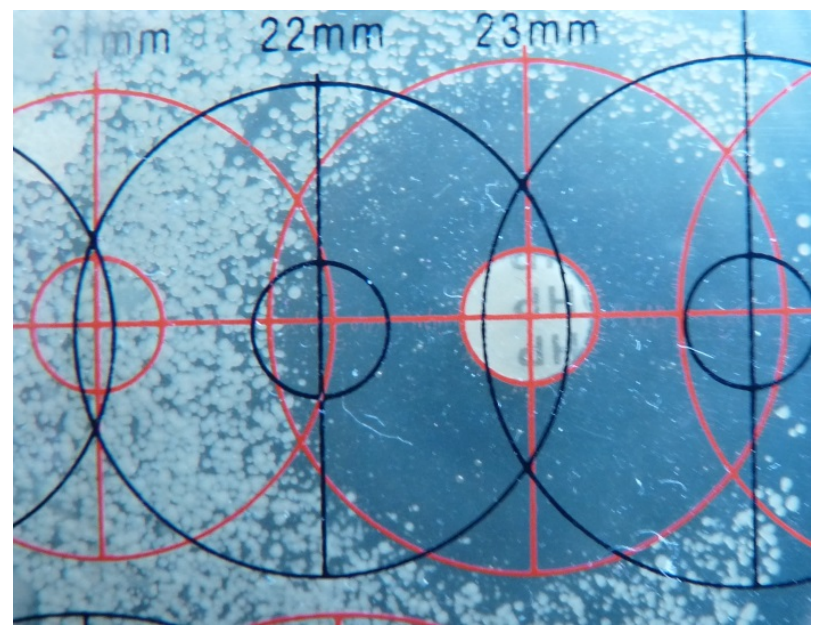

Рис. 9. Визначення чутливості виділених пастерел до енроксилу

Досить високу чутливість збудник продемонстрував до тилозину (рис. 11). Із даним антибактерійним засобом зона затримки росту становила 18-20 мм. Найвища чутливість пастерел встановлена до енрофлоксацину, де зона затримки росту становила 19-23 мм (рис.12)Хворих тварин забезпечили значною кількістю сіна високої якості та соломою. Для меншого травмування слизової оболонки ротової порожнини кролям згодовували варені овочі (картоплю, буряк), запарені вологі мішанки, з додаванням відвару льону у якості обволікаючого засобу. Замість води ввечері тваринам випоювали відвар із ромашки.

Оскільки хворі тварини знаходилися в одному приміщенні, а кількість хворих була значною, існувала висока ймовірність швидкого перезараження тварин та знаходження їх в інкубаційному періоді.

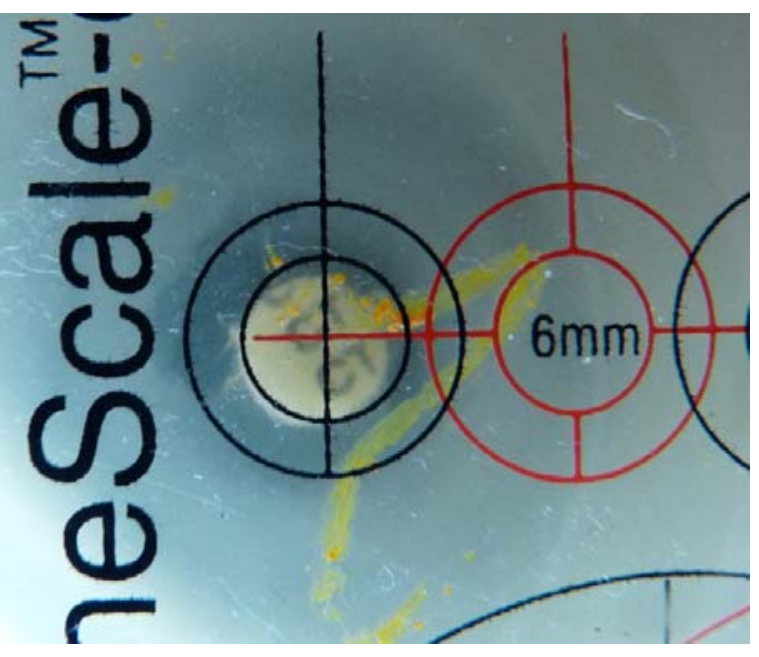

Рис. 10. Низька чутливість збудника до стрептоміцину

Тому ізоляцію клінічно хворих тварин не проводили: усім кролям вводили антибактерійні речовини. При виборі антибактеріальних речовин враховували чутливість до них збудників пастерельозу та стафілококозу. Найвища чутливість пастерел та стафілококів була встановлена до енрофлоксацину. Але в інструкції по застосуванню кролям енрофлоксацин не було рекомендовано. Тому було прийнято рішення щодо застосування тилозину.

Хворих тварин було поділено на дві підгрупи. Тваринам першої застосовували Тилозин 50. Препарат вводили внутрішньом'язово один раз на добу протягом 5 діб за добової норми для кролів 0,3 мл на 1 кг маси тіла.

Чутливість виділених стафілококів до окремих антибактерійних засобів

\begin{tabular}{|l|c|c|}
\hline Назва препарату & Зона затримки росту мікрофлори, & Категорії чутливості \\
\hline Амоксіцилін & $2-4$ & Резистентний \\
\hline Доксіциклін & $2-4$ & Резистентний \\
\hline Поліміксин & - & Резистентний \\
\hline Тілозин & $18-20$ & Чутливий \\
\hline Енрофлоксацин & $19-23$ & Чутливий \\
\hline Тетрациклін & - & Резистентний \\
\hline Неоміцин & $4-6$ & Резистентний \\
\hline Цефазолін & $2-4$ & Резистентний \\
\hline Левоміцетин & $8-12$ & Помірно-стійкий \\
\hline Канаміцин & $10-14$ & Помірно-стійкий \\
\hline
\end{tabular}

Оскільки при дослідженні фекалій у тварин були виявлені ооцисти еймерій необхідно було провести санацію організму тварин від найпростіших. Тому кролям цієї групи застосовували препарат «Солікокс». В 1 мл цього препарату міститься 2,5 мг діклазуріла. Найбільш чутливі до препарату нестатеві стадії ендогенного циклу розвитку кокцидій. Діклазуріл не викликає негативних наслідків навіть при перевищенні рекомендованих доз в 25-50 разів. Препарат задавали у дозі 0,4 мл на 1 кг маси тіла на добу з питною водою протягом 2 діб, що відповідає 1 мг діючої речовини на 1 кг маси тіла на добу.

Хворим тваринам другої групи застосовували бровасептол - комплексний препарат, що містить в 1 г 80 мг норсульфазолу, 70 мг сульгіну, 30 мг триметоприму, 45 мг окситетрацикліну, 25 мг тілозину. Препарат задавали з комбікормом протягом 3 днів підряд, у дозі 1 г на 10 кг живої маси. Застосування даного преперету дало змогу одночасно лікувати тварину від пастерельозу та еймеріозу. 


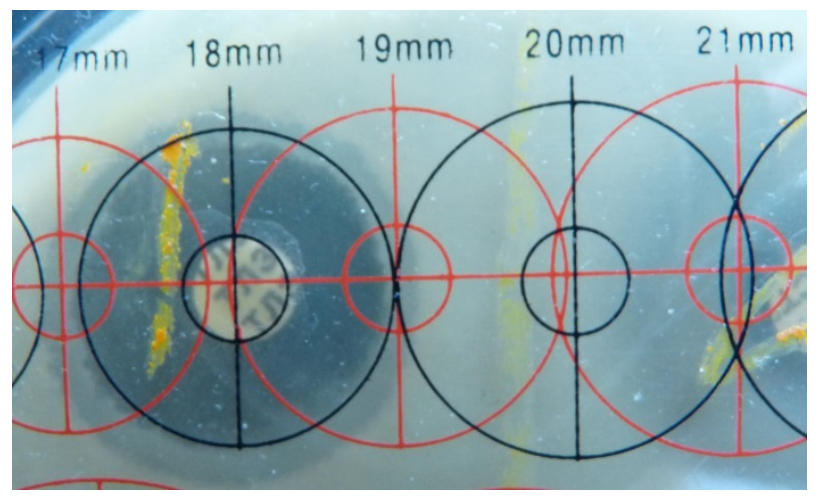

Рис. 11. Визначення чутливості стафілококів до тилозину

Через тиждень після одужання тварин усіх кролів щеплювали вакциною. Пазорін-Оль, (Pasorin-Ol )- вакциною проти пастерельозу кролів. Тваринам від 4 до 6 тижнів вакцину вводили підшкірно по 0,5 мл, кролям у віці понад 7 тижнів - по 1 мл.

Проводили дезінфекцію кліток відкритим вогнем паяльної лампи. Гній, підстилку, залишки кормів, тару та малоцінний інвентар спалювали. Усе поголів'я кролів у загрозливій зоні рекомендували щеплювати вакциною Пазорін-Оль згідно інструкції щодо використання. Впродовж двох місяців після останнього випадку захворювання не завозили нове поголів'я кролів.

\section{Висновки}

1. Проведено аналіз розвитку ензоотії пастерельозу кролів, ускладненого стафілококозом і вірусним стоматитом, описані клінічні ознаки, патологоанатомічні зміни у різновікових тварин.

2. При розробці заходів боротьби враховували наявність асоціації. У даному господарстві одночасно 3 асоційованим пастерельозом було діагностовано еймеріоз, тому крім антибактеріальних речовин виникала необхідність у застосуванні еймеріостатиків. Вибір антибактеріальних засобів був обгрунтований результатами визначення чутливості до них виділеної мікрофлори. У даному господарстві виділені збудники виявляли чутливість до енрофлоксацину та тилозину. Тваринам однієї групи був застосований комплексний препарат бровасептол, що дало змогу провести заходи боротьби одночасно $з$ пастерельозом та еймеріозом. У іншій застосували препарат тилозин 50\% та салікокс.

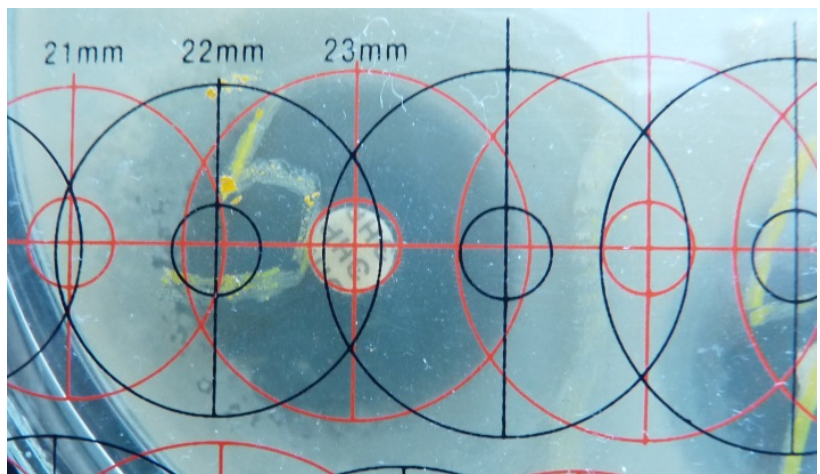

Рис. 12. Дослідження чутливості виділеного збудника до енрофлоксацину

Бровасептол задавали 3 комбікормом протягом 3 днів підряд, у дозі 1 г на 10 кг живої маси. Тилозин вводили внутрішньом'язово у дозі 0,3 мл на 1 кг маси тіла один раз на добу протягом 5 діб.

3. Високий лікувальний ефект забезпечило застосування біопрепаратів серед тварин обох груп. Застосування тилозину було ефективним як окремо, у поєднанні з солікоксом, так і при застосуванні комплексного препарату бровасептолу. Через тиждень після одужання тварин проводили щеплення усіх кролів вакциною Пазорін-Оль.

\section{Бібліографічні посилання}

Trishkina, E.T., Parfenov, I.S. (1987). Racional'naja antibiotikoterapija pasterelleza sel'skohozjajstvennyh zhivotnyh. Tr. VI-JeV. 65, 142-147 (in Russian).

Sosnyc'kyj, O.I. (2003). Patogenez pasterel'oznoi' infekcii' u kroliv. Agrar. visn. Prychornomor'ja: zb. nauk. prac'. Derzh. agrar. un-t. - Odesa. 21, 170 - 173 (in Ukrainian).

Evtushenko, A.F. (1992). Bolezni krolikov. K.: «Urozhaj» (in Russian).

Zabolotnaja, V.P., Sosnickij, A.I. (1999). Pasterelly - kak odin iz vozbuditelej associativnyh infekcij (Osobennosti kul'tivirovanija pasterel). Materialy nauch. sesii Rossel'hozakademii. M. : Rossel'hozakademija. 1, 240 -241 (in Russian).

Zabolotna, V.P. (2005). Variabel'nost' respiratornyh parazitocenozov faktornogo tipa oslozhnennyh $\mathrm{P}$. Multocida. Zb. nauk. prac' Lugan. nac. agrar. un-tu Lugans'k. 50/73, 60 - 69 (in Russian).

Стаття надійшла до редакиії 22.08.2016 